\title{
EVALUASI IMPLEMENTASI PROGRAM PENGABDIAN MASYARAKAT TEMATIK POSDAYA BERBASIS MASJID UNIVERSITAS ISLAM NEGERI SULTAN SYARIF KASIM RIAU
}

\author{
Herlinda \\ Dosen Fakultas Ekonomi dan Ilmu Sosial \\ Universitas Islam Negeri Sulthan Syarif Kasim Riau \\ email: herlindauin@gmail.com
}

\begin{abstract}
Abstrak
Tujuan dari penelitian ini adalah evaluasi (1) kesesuaian kebijakan, tujuan, sasaran, dan kebutuhan latar belakang terhadap Standar Program PPM, (2) kesesuaian kesiapan SDM, memperlengkapi siswa, kesiapsiagaan masyarakat terhadap Standar Program PPM, (3) kesesuaian program implementasi yang direncanakan dan partisipasi masyarakat terhadap Standar Program PPM, (4) Kesesuaian pencapaian hasil penerapan Program PPM Positif Tematik terhadap Standar Program PPM. Metode yang digunakan adalah metode deskriptif, dimana model yang digunakan adalah CIPP (Konteks, Input, Proses dan Produk). Hasil dari penelitian ini adalah (1) kebijakan, tujuan, tujuan, dan kebutuhan latar belakang sesuai dengan standar pelaksanaan, (2) kesiapan SDM, memperlengkapi siswa, kesiapsiagaan masyarakat sesuai pelaksanaannya. standar, (3) pelaksanaan, pemantauan dan evaluasi, dan pelaporan dan partisipasi masyarakat sesuai dengan standar pelaksanaan, (4) pencapaian res Penggunaan Program PPM Tematik Posdaya sesuai Standar Program $P P M$.
\end{abstract}

Kata Kunci: Program Pelayanan Masyarakat Positif Tematik Berdasarkan Masjid, konteks, masukan, proses, produk.

\section{PENDAHULUAN}

Pengabdian masyarakat UIN Suska Riau dilaksanakan dalam bentuk pengembangan pemberdayaan keluarga (posdaya berbasis masjid) merupakan instrumen pemberdayaan umat yang memiliki peran yang sangat strategis dalam upaya peningkatan kualitas masyarakat, dan didukung oleh manajemen pengelolaan masjid yang baik dan terpadu. Untuk mewujudkan pengamalan Tri Dharma Perguruan Tinggi, mulai tahun 2011 UIN Suska Riau telah melaksanakan program pengabdian masyarakat dalam bentuk kegiatan Kuliah Kerja Nyata (KKN). Program Pengabdian Masyarakat Tematik Posdaya Berbasis Masjid dirancang secara berkelanjutan, karena itu hasil yang diharapkan dapat dicapai secara bertahap hingga tahun 2015. Kuliah kerja nyata angkatan XXXIX tahun 2015 Kecamatan Tandun Kabupaten Rokan Hulu terdiri dari
Desa Tapung Jaya, Sungai Kuning, Kumain, Tandun Barat, Bono Tapung, Dayo, Koto Tandun, Puo Raya, dan Tandun. Pengabdian Masyarkat Berbasis Masjid dilakukan untuk memperkuat kembali sejarah peran masjid sebagai sarana untuk melakukan perubahan sosial dalam rangka untuk mempercepat capaian indikator pembangunan Millinium atau Millinium Development Gools (MDGS) yakni delapan sasaran atau tujuan yang telah disetujui dan dipolopori oleh PBB. Ada delapan sasaran atau tujuan yang ingin dicapai di tahun 2012 adalah sebagai berikut:

1. Menghapuskan kemiskinan dan kelaparan,

2. Pencapaian pendidikan dasar secara universal,

3. Mengembangkan kesetaraan gender dan memberdayakan perempuan,

4. Mengurangi kematian ibu dan anak, 
5. Meningkatkan kesehatan ibu,

6. Perlawanan HIV/AIDS, malaria dan penyakit mematikan lainnya,

7. Menjamin keberlanjutan lingkungan dan

8. Mengembangkan kemitraan global untuk pembangunan.

Penelitian ini difokuskan pada

Evaluasi Implementasi Program

Pengabdian Masyarakat Tematik Posdaya

Berbasis Masjid di Universitas Islam

Negeri Sultan Syarif Kasim Riau.

Berdasarkan fokus penelitian, maka dapat dibuat daftar pertanyaan perumusan masalah adalah:

1. Bagaimana kesesuaian antara kebijakan, tujuan, sasaran, dan latar kebutuhan program PPM Tematik Posdaya dengan Standar Program Pengabdian Masyarakat Tematik Posdaya Berbasis Masjid Universitas Islam Negeri Sultan Syarif Kasim Riau?, Hal ini sesuai dengan teori menurut Mukhtar, mengungkapkan: Sehubungan dengan penetapan kebutuhan pendidikan, faktor siswa, orang tua, masyarakat, dan pendidik merupakan subjek yang harus dipenuhi kebutuhannya dalam pelaksanaan kegiatan pendidikan dan pengajaran di sekolah. Orang-orang tersebut merupakan aspek yang harus dipenuhi kebutuahnnya dalam perencanaan pendidikan (Mukhneri Mukhtar, 2012:61).

2. Bagaimanakah kesesuaian antara kesiapan SDM, pembekalan mahasiswa, dan kesiapan masyarakat program PPM Tematik Posdaya dengan standar Program Pengabdian Masyarakat Tematik Posdaya Berbasis Masjid di UIN Suska Riau? Hal ini sesuai dengan teori menurut

John

M.Ivancevich, Robert Konopaske, kemampuan professional yang dituntut dari seseorang adalah kemampuan mengidentifikasi subyek-subyek yang mempunyai potensi untuk memberikan berbagai input dan sumber bagi proses pembangunan (John M.Ivancevich, Robert Konopaske,2013:131).
3. Bagaimanakah kesesuaian antara pelaksanaan atas keseluruhan program yang telah direncanakan serta partisipasi masyarakat program PPM Tematik Posdaya dengan standar program Pengabdian Masyarakat Tematik Posdaya Berbasis Masjid di UIN Suska Riau?. Meliputi evaluasi yang telah dirancang dan diterapkan didalam proses penilaian proses mungkin sebagai pemonitor sistem pengumpulan data dari pelaksanaan program (Nana Sudjana, 1989:246).

4. Bagaimanakah kesesuaian antara ketercapaian hasil penerapan program PPM Tematik Posdaya dengan standar program Pengabdian Masyarakat Tematik Posdaya Berbasis Masjid di Uin Suska Riau?. Hal ini sesuai dengan teori menurut Miller Outputs are designed and delivered spesifically for the purpose of meeting or exceeding the needs and requirements of customers, stekeholders, fakulty, and staff. (Output dirancang dan disampaikan secara khusus untuk tujuan memenuhi atau memenuhi kebutuhan dan persyaratan pelanggan dan stakeholder) (Barbara A.Miller, 2007:66).

Tujuan penelitian adalah untuk mengetahui

1. Kesesuaian antara kebijakan, tujuan, sasaran, dan latar kebutuhan program PPM Tematik Posdaya dengan Standar Program Pengabdian Masyarakat Tematik Posdaya Berbasis Masjid Universitas Islam Negeri Sultan Syarif Kasim Riau,

2. Kesesuaian antara kesiapan SDM, pembekalan mahasiswa, dan kesiapan masyarakat program PPM Tematik Posdaya dengan standar Program Pengabdian Masyarakat Tematik Posdaya Berbasis Masjid di Universitas Islam Negeri Sultan Syarif Kasim Riau,

3. Kesesuaian antara pelaksanaan atas keseluruhan program yang telah direncanakan serta partisipasi masyarakat program PPM tematik Posdaya dengan standar program 
Pengabdian Masyarakat Tematik Posdaya Berbasis Masjid di UIN Sultan Syarif Kasim Riau,

4. Kesesuaian antara ketercapaian hasil penerapan program PPM Tematik Posdaya dengan standar program Pengabdian Masyarakat Tematik Posdaya Berbasis Masjid di Uin Sultan Syarif Kasim Riau.

\section{TINJAUAN PUSTAKA}

Evaluasi adalah proses perancangan sketsa, pemerolehan, dan pemberian penggunaan informasi dalam rangka memberikan pendapat atas alternatif pilihan keputusan. Tyler dalam Tayibnapis mengungkapkan evaluasi adalah proses yang menentukan sampai sejauh mana tujuan dapat dicapai (Farida Yusuf Tayibnapis,2008:3). Pandangan lain tentang evaluasi dikemukakan oleh Rossi, yakni," Evaluation is social research applied to answering policy-oriented questions" (Peter H. Rossi, 2004:127).

Pengertian selanjutnya tentang evaluasi program adalah suatu rangkaian kegiatan yang dilakukan dengan sengaja untuk melihat tingkat keberhasilan program (Suharsimi Arikunto,2009:290).

Mc.David and Hawthorn menjelaskan, "A program can be thought as a group of related activities that is intended to achieve one or several objectives. Program are means-ends relationship that are designed and implemented purposively" (James C. Mc.David, Laura R.L.Hawthorn,2006:15).

Madaus and Stufflebeam menetapkan model evaluasi, yaitu: Objective/goalsbased, Experimental/field trials, Decision oriented (DOER), Consumeroriented, Costbased evaluation, CIPP Model merupakan sebuah kerangka kerja yang menyeluruh untuk memandu evaluasi formatif dan sumatif evaluasi program (George F. Madaus and Daniel L. Stufflebeam, 2006:26-28).

Formative/summative evaluation, evaluasi formatif dilakukan selama pengembangan atau peningkatan program atau produk, sedangkan sumatif evaluasi dilakukan setelah penyelesaian dan untuk kemanfaatan pihak eksternal atau pengambil keputusan.

Model evaluasi program CIPP (Context, Input, Process, and Product) adalah model yang dikembangkan oleh Stuffleabeam. Evaluasi program adalah proses untuk mendeskripsikan dan menilai suatu program dengan menggunakan kriteria tertentu dengan tujuan untuk membantu merumuskan keputusan, kebijakan yang lebih baik.

CIPP Evaluasi Model pada garis besarnya melayani empat macam keputusan, yaitu :

1. Perencanaan keputusan yang mempengaruhi pemilihan tujuan umum dan khusus.

2. Keputusan pembentukan atau structuring, yang kegiatannya mencakup pemastian strategi optimal dan desain proses untuk mencapai tujuan yang telah diturunkan dari keputusan perencanaan,

3. Keputusan implementasi, dimana pada keputusan ini para evaluator mengusahakan sarana prasarana untuk menghasilkan dan meningkatkan pengambilan keputusan atau eksekusi, rencana, metode dan strategi yang hendak dipilih,

4. Keputusan pemutaran (recycling) yang menentukan, jika suatu program itu diteruskan, diteruskan dengan modifikasi dan atau diberhentikan secara total atas dasar kriteria yang ada.

Pengabdian Masyarakat Tematik POSDAYA Berbasis Masjid merupakan model berpikir sistem yang dimulai dari konteks, masukan, proses dan hasil produk, maka model penelitian yang dipilih adalah CIPP, dengan jenis evaluasi formatif. Evaluasi formatif digunakan untuk memperbaiki program selama program tersebut sedang berjalan. Selain itu evaluasi ini memberikan data yang relatif cepat (short term data). Pendapat ini didukung oleh Scriven yang menyatakan CIPP Model sebuah kerangka kerja yang menyeluruh untuk memandu evaluasi formatif dan 
sumatif evaluasi program (Daniel L.Stufflebeam,2004:245).

Berdasarkan model evaluasi CIPP, skema evaluasi program program Pengabdian Masyarakat Tematik POSDAYA Berbasis Masjid., sebagaimana pada gambar berikut.

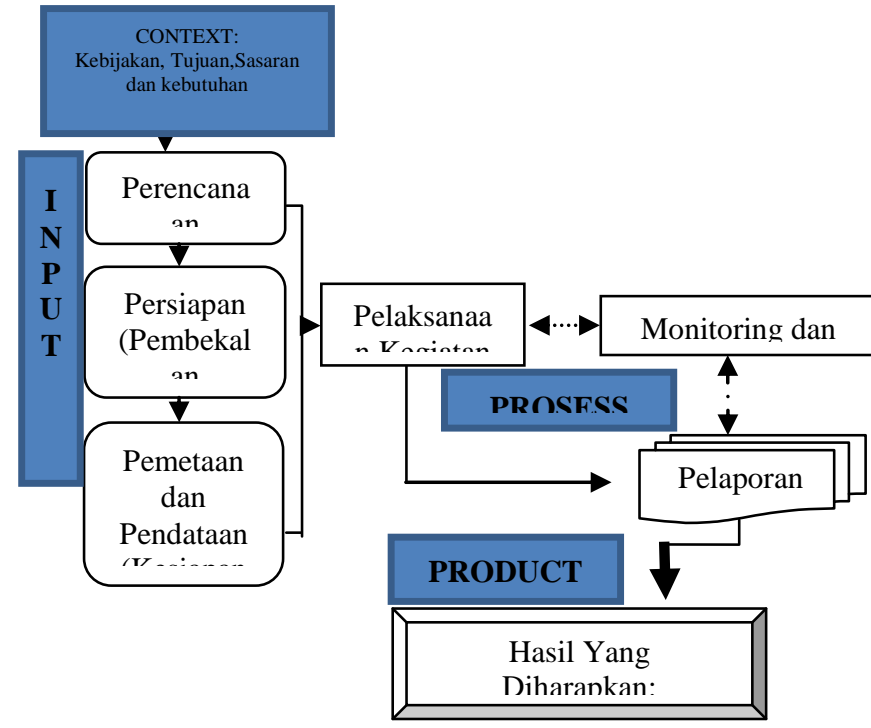

Gambar: Skema Program Pengabdian Masyarakat Tematik Berbasis Masjid UIN SUSKA Riau

Fungsi manajermen diungkapkan oleh Terry dalam definisi manajemen yang lebih luas "management is a distinct process consisting of planning, organizing, actuating, and controlling" (George R. Terry, 1976:4).

Selanjutnya, tentang pemahaman perencanaan Robbins and Coulter menyatakan "planning involves defining plans to integrate and coordinate work activities. It's concerned with boths ends (what) and means (how) (Stephen P.Robbins, Mary Cuolter,2012:204).

Kemudian, Daft menjelaskan "the organizing process leads to the creation of organization structure, which defines how tasks are divide and resources deployed" (Richard L. Daft, 2010:115).

Mukhtar menyatakan, penggerakan (leading) merupakan tindakan mengusahakan agar anggota kelompok berusaha untuk mencapai sasaran-sasaran sesuai dengan usaha-usaha organisasi (Mukhneri Mukhtar, 2012:66).

Schermerhorn berpendapat "controlling is a process of measuring performance and taking action to ensure desire result (John R. Schermerhorn, 2010: 462).

\section{METODOLOGI PENELITIAN}

Pada penelitian ini, teknik analisa data menggunakan metode kualitatif dengan metode evaluasi program CIPP. Teknik pengambilan data secara observasi, wawancara serta dokumentasi. Sesuai dengan tujuan penelitian dan model evaluasi program yang dipilih, maka desain penelitian yang digunakan adalah Model Desain Evaluasi Context, Input, Process dan Product (CIPP).

Disain penelitian evaluasi implementasi Program Pengabdian Masyarakat Tematik Posdaya Berbasis Masjid di Universitas Islam Negeri Sultan Syarif Kasim Riau adalah : 
Tabel 1. Desain Penelitian

\begin{tabular}{|c|c|c|}
\hline $\begin{array}{l}\text { KOMPONEN } \\
\text { EVALUASI }\end{array}$ & $\begin{array}{c}\text { ASPEK } \\
\text { SUBKOMPONEN }\end{array}$ & HASIL \\
\hline 1. Latar Belakang & $\begin{array}{l}\text { 1. Kebijakan } \\
\text { 2. Tujuan } \\
\text { 3. Sasaran } \\
\text { 4. Kebutuhan }\end{array}$ & \multirow[t]{4}{*}{$\begin{array}{l}\text { Terbentuknya kelompok kerja posdaya } \\
\text { berbasis masjid secara aktif dan berkelanjutan }\end{array}$} \\
\hline 2. Input & $\begin{array}{l}\text { 1. Kesiapan SDM } \\
\text { 2. Kesiapan Masyarakat } \\
\text { 3. Pembekalan Mahasiswa }\end{array}$ & \\
\hline 3. Proses pelaksanaan & $\begin{array}{l}\text { 1. Terlaksananya keseluruhan } \\
\text { program yang telah } \\
\text { direncanakan } \\
\text { 2. Keikutsertaan masyarakat } \\
\text { secara aktif dalam } \\
\text { pelaksanaan program }\end{array}$ & \\
\hline 4. Produk atau Hasil & $\begin{array}{l}\text { 1. Meningkatnya kesehatan ibu } \\
\text { dan anak } \\
\text { 2. Meningkatnya angka minat } \\
\text { sekolah dasar } \\
\text { 3. Diharapkan Meningkatnya } \\
\text { kesadaran menjaga } \\
\text { kebersihan lingkungan rumah } \\
\text { 4. Meningkatnya perekonomian } \\
\text { keluarga }\end{array}$ & \\
\hline
\end{tabular}

REKOMENDASI

Adapun Kriteria evaluasi yang akan digunakan dapat dilihat pada tabel di bawah ini:

Tabel 2. Kriteria Evaluasi

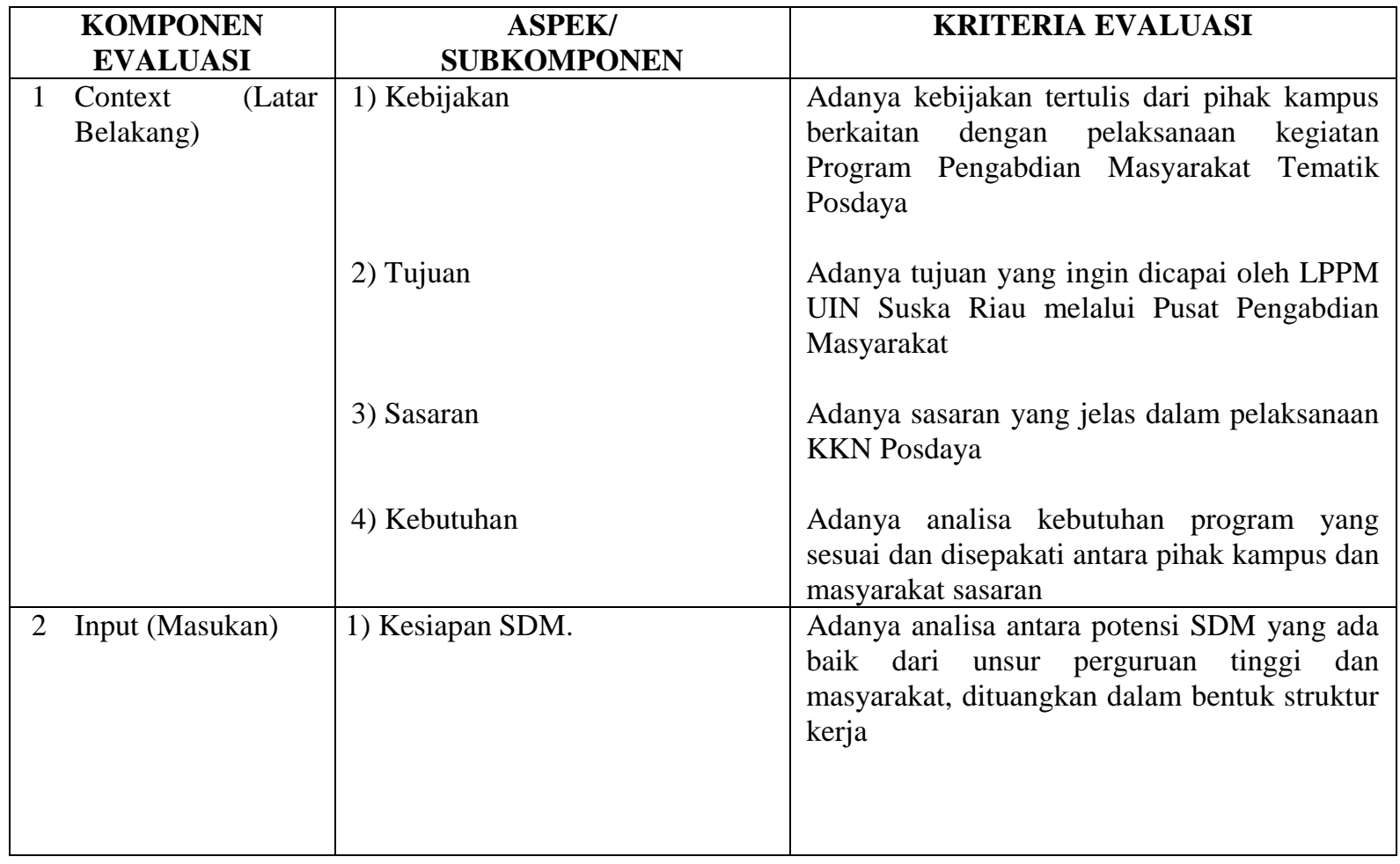




\begin{tabular}{|c|c|c|}
\hline & $x^{2}$ & $\begin{array}{l}\text { Adanya kegiatan pembekalan terhadap } \\
\text { mahasiswa berkaitan dengan permasalahan } \\
\text { teknis maupun administrative pelaksanaan } \\
\text { program PPM Posdaya yang dilakukan dalam } \\
\text { bentuk pelatihan atau work shop. } \\
\text { Adanya kesiapan masyarakat untuk mengikuti } \\
\text { program kerja PPM Posdaya yang telah } \\
\text { disepakati bersama yang dituangkan dalam } \\
\text { bentuk kegiatan serah terima mahasiswa KKN } \\
\text { dengan perangkat desa. }\end{array}$ \\
\hline Process (Proses) & $\begin{array}{l}\text { 1) Terlaksananya keseluruhan } \\
\text { program yang telah } \\
\text { direncanakan } \\
\text { 2) Keikutsertaan masyarakat } \\
\text { secara aktif dalam } \\
\text { pelaksanaan program }\end{array}$ & $\begin{array}{l}\text { Seluruh program terlaksana capaian secara } \\
\text { berkala } \\
\text { Unsur masyarakat ikut berperan serta secara } \\
\text { aktif yang ditunjukkan dengan foto-foto } \\
\text { kegiatan }\end{array}$ \\
\hline 4 Product (Hasil) & $\begin{array}{l}\text { 3) Meningkatnya kesadaran } \\
\text { menjaga kebersihan } \\
\text { lingkungan rumah } \\
\text { 4) Meningkatnya perekonomian } \\
\text { keluarga }\end{array}$ & $\begin{array}{l}\text { Berkurangnya data ibu dan anak sakit yang } \\
\text { dituangkan dapat bentuk data angket } \\
\text { wawancara dengan masyarakat penguna } \\
\text { kebijakan } \\
\text { Meningkatnya minat anak masih sekolah dasar } \\
\text { sesuai kriteria usia yang proporsional } \\
\text { ditunjukkan dengan perkembangan minat } \\
\text { sekolah } \\
\text { Meningkatnya kesadaran menjaga kebersihan } \\
\text { lingkungan rumah yang ditunjukkan dengan } \\
\text { adanya sarana MCK, kebersihan halaman dan } \\
\text { dalam rumah yang diobservasi secara berkala } \\
\text { Meningkatnya kreatifitas ibu rumah tangga } \\
\text { dalam membantu } \\
\text { perekonomian keluarga }\end{array}$ \\
\hline
\end{tabular}

\section{HASIL PENELITIAN DAN PEMBAHASAN}

\subsection{Hasil Penelitian Evaluasi Context (Konteks)}

Evaluasi konteks (context) mencakup analisis masalah yang berkaitan dengan lingkungan program yang akan atau telah dilaksanakan. Hal tersebut berisi tentang analisis kekuatan dan kelemahan objek tertentu. Evaluasi konteks sebagai fokus kelembagaan untuk mengidentifikasi peluang dan menilai kebutuhan. Suatu kebutuhan dirumuskan sebagai kesenjangan antara kondisi nyata dengan kondisi yang diharapkan.

Konteks dalam fungsi manajemen, pada hakekatnya termasuk dalam fungsi perencanaan.Mukhtar menyatakan dalam suatu perencanaan yang baik, harus ditetapkan kebijaksanaan untuk mencapai tujuan dalam garis besarnya (Mukhneri Mukhtar, 2012:61).

Tujuan merupakan bagian dari suatu perencanaan stratejik organisasi.Tujuan program ditetapkan setelah dilakukan penilaian kebutuhan terhadap program. Schermerhon menyatakan tujuan dan sasaran dapat berhasil diimplementasikan, jika memenuhi kriteria; spesifik, tepat waktu, terukur, menantang, dan dapat dicapai.

Sebagaimana penilaian kebutuhan berdasarkan pendekatan deduktif, maka ruang lingkup program yang merupakan hasil yang diharapkan dapat dicapai yang tertuang dalam dokumen Program Pengabdian Masyarakat Tematik Posdaya Berbasis Masjid di Universitas Islam Negeri Sultan Syarif Kasim Riau tahun 2015 adalah: 
1. pengembangan sosial budaya masyarakat yang berorientasi kepada pemberdayaan masyarakat agama,

2. Pemberdayaan masyarakat melalui pendidikan, pelatihan dan kewirausahaan untuk meningkatkan perekonomian keluarga,

3. Melakukan pemberantasan buta aksara,

4. Pengembangan usaha kecil dan menengah dalam konteks syariah,

5. Kerja bakti,

6. Pelayanan kesehatan,

7. Pembinaan kesenian dan olah raga,

8. Pengelolaan sumber daya alam dan lingkungan,

9. Gerakan cinta lingkungan dan penghijauan, dan

10. Gerakan hidup sehat dengan menjaga kerbersihan lingkungan.

\subsection{Hasil Penelitian Evaluasi Masukan} (Input)

Evaluasi masukan (input) menilai SDM, dan anggaran untuk studi kelayakan dan efektifitas biaya dalam mencapai tujuan program Pengabdian Masyarakat Tematik Posdaya Berbasis Masjid di UIN Suska Riau perlu ditetapkan kesiapan sumber daya manusia.

Hasil evaluasi aspek kesiapan SDM menunjukkan hasil yang sesuai dengan standar program PPM Tematik Posdaya. Hal ini didasari atas analisa potensi SDM yang telah dituangkan dalam bentuk struktur kerja yang jelas.

Selain kesiapan SDM, pembekalan mahasiswa merupakan aspek yang sangat menentukan dalam pencapaian keberhasilan pelaksanaan KKN PPM Tematik Posdaya Pemebekalan mahasiswa bertujuan untuk;

1. Memotivasi mahasiswa belajar bersama bermasyarakat,

2. Mendorong mahasiswa untuk dapat bekerjasama dengan masyarakat dan mampu sebagai problem solver di tengah-tengah masyarakat,

3. Mendorong mahasiswa untuk memahami kompleksitas masalah yang dihadapi masyarakat,
4. Mendorong mahasiswa secara bersamasama untuk membantu masyarakat membantu mewujudkan kehidupan yang sejahtera melalui pembentukan Posdaya, dan

5. Mendorong mahasiswa untuk ikut membantu mengembangkan potensi daerah bersama-sama masyarakat dalam meningkatkan kesejahteraan seluruh masyarakat di lokasi KKN.

\subsection{Hasil Penelitian Evaluasi Proses} (Process)

Evaluasi proses, menilai implementasi perencanaan dalam rangka untuk menyampaikan kepada pihak luar, dan selanjutnya membantu para pihak pengguna lainnya yang memberikan pendapat tentang kinerja dan yang menginterpretasikan outcomes. Komponen proses dalam evaluasi program program Pengabdian Masyarakat Tematik Posdaya Berbasis Masjid, mencakup aspek pelaksanaan, dengan kriteria seluruh program terlaksana yang ditunjukkan dengan capaian secara berkala yang ditunjukkan dari kegiatan monitoring dan pelaporan, dan aspek keikut sertaan masyarakat secara aktif dalam pelaksanaan program dengan kriteria unsur masyarakat ikut berperan serta secara aktif yang ditunjukkan dengan daftar absensi kegiatan.

\subsection{Hasil Penelitian Evaluasi Produk (Product)}

Evaluasi produk, mengidentifikasi dan menilai outcomes yang diharapkan dan yang tidak diharapkan, baik jangka panjang maupun jangka pendek dalam rangka membantu organisasi untuk menjaga organisasi fokus dalam pencapaian outcomes yang penting, dan membantu para pihak lainnya untuk mengukur pengaruh keberhasilan suatu target keinginan yang disepakati.

Menurut Miller Outputs are designed and delivered spesifically for the purpose of meeting or exceeding the needs and requirements of customers, stekeholders, fakulty, and staff (Barbara A.Miller, 2007:66). 
Output program KKN PPM Tematik Posdaya adalah ruang lingkup komponen program KKN PPM Tematik Posdaya yang dimulai dari perencanaan dalam bentuk penetapan kebijakan, analisis kebutuhan, penetapan kesiapan SDM, pembekalan mahasiswa dan kesiapan masyarakat input, pelaksanaan sampai dengan pertanggung jawaban proses, dan pada akhirnya menghasilkan dalam bentuk produk program MDGs

\section{PENUTUP}

Berdasarkan hasil penelitian yang telah dilaksanakan dilapangan dan pembahasan hasil evaluasi implementasi Program Pengabdian Masyarakat Tematik Posdaya Berbasis Masjid di Universitas Islam Negeri Sultan Syarif Kasim Riau menggunakan komponen Context (konteks), Input (masukan), Process (proses), dan Product (hasil), diperoleh hasil:

1. Komponen konteks (context) meliputi kebijakan, tujuan, sasaran, dan latar kebutuhan dapat disimpulkan secara keseluruhan sesuai dengan standar program LPPM.,

2. Masukan (input) dalam evaluasi model CIPP, meliputi aspek kesiapan SDM, pembekalan mahasiswa, dan kesiapan masyarakat secara keseluruhan sesuai dengan standar Program LPPM.,

3. Komponen ketiga adalah proses (process) yang meliputi aspek pelaksanaan, monitoring dan evaluasi, dan pelaporan dengan satu kriteria pengukuran keberhasilan, dan aspek keikut sertaan masyarakat secara aktif secara keseluruhan sesuai dengan standar program LPPM.,

4. Komponen terakhir adalah produk (product) yang merupakan hasil dari program Pengabdian Masyarakat Tematik. Berdasarkan evaluasi antara kesesuaian kriteria keberhasilan dengan standar, dapat disimpulkan bahwa secara keseluruhan sesuai dengan standar programPengabdian Masyarakat Tematik Posdaya Berbasis Masjid di
Universitas Islam Negeri Sultan Syarif Kasim Riau.

Sebagai wacana ke depan perlu beberapa pemikiran yang diharapkan dapat menjadi kontribusi bagi Universitas, LPPM, SDM, mahasiswa, dan masyarakat adalah :

1. Kepada Pembuat kebijakan Universitas Islam Sultan Syarif Kasim Riau, untuk menyatukan persepsi di masa yang akan datang, dengan menyatukan Tema KKN agar lebih mudah di evaluasi keberhasilannya,

2. Lembaga LPPM sebagai penyelenggara KKN UIN Suska Riau, untuk lebih meningkatkan keterampilan dosen-dosen pembimbing supaya lebih terampil dalam memberi arahan kepada mahasiswa tentang pelaksanaan program-program KKN di lapangan. Kemudian memberi pembekalan mental spiritual para mahasiswa sebagai calon peserta, karena mental yang kuat, tangguh dan profesional sangat dibutuhkan untuk dapat berdaptasi dan kondisi di area sasaran yang hendak dituju.Pembekalan sebaiknya dilakukan jauh lebih awal, baik pembekalan keagamaan, pembekalan kepemimpinan maupun pembekalan terhadap apa yang dilaksanakan terkait tema kuliah kerja nyata tematik nantinya supaya mahasiswa lebih potensial dalam beradaptasi dengan masyarakat,

3. Sebelum mahasiswa diturunkan ke lokasi KKN, pihak Lembaga Pengabdian pada Masyarakat sebaiknya menggambarkan kondisi daerah tempat pelaksanaan KKN kepada mahasiswa. Apabila lokasi KKN yang akan dituju tidak memungkinkan untuk dapat terlaksananya program $\mathrm{KKN}$, maka sebaiknya mahasiswa tidak diturunkan ke daerah tersebut, karena daerah terisolir sulit bagi mahasiswa untuk menjalankan program KKN yang sudah direncanakan oleh LPPM, juga bagi dosen pembimbing sulit untuk memonitoring proses kegiatan 
mahasiswa, karena terputusnya akses transportasi menuju ke lokasi KKN,

4. Kepada seluruh lapisan masyarakat penerima manfaat KKN untuk tercapainya misi program KKN UIN Suska Riau, maka masyarakat, tokoh masyarakat, karang taruna, posyandu, PKK, majelis taklim dan para pengurus masjid hendaknya dapat lebih mengaplikasikan Posdaya yang telah disosialisasikan oleh mahasiswa KKN UIN Suska Riau setelah berakhirnya KKN.

\section{DAFTAR PUSTAKA}

Alkin Marvin C,and Christie Christina A., An Evaluation Theory Tree, dalamEvaluation Roots, California: Sage Publications, Inc, 2004.

Arikunto, Suharsimi, Dasar-dasar Evaluasi Pendidikan. Jakarta: Bumi Aksara,2009.

Arikunto, Suharsimi dan Safrudin Cepi, Evaluasi Program Pendidikan:Pedoman Teoritis Bagi Mahasiswa dan Praktisi Pendidikan,Jakarta: Bumi Aksara, Cetakan ketiga, 2009.

Barbara A. Miller, Assesing Organizational Performance Higher Education, (San Fransisco : John Willey \& Sons), 2007.

Craven Eugene, Evaluating Program Performance, dalam ImprovingAcademic

Management,San Francisco: JosseyBass Inc, Publishers, 1980.

Chen Huey- Tsyh, The Roots of TheoryDriven Evaluation, dalam Evaluation Roots, California: Sage Publication. Inc, 2004.Direktorat Jenderal Pendidikan Tinggi, Pedoman Program Pengabdian Masyarakat, Jakarta: Direktorat Penelitian dan Pengabdian Masyarakat, 2010.

Eti Rochaety - Pontjorini Rahayuningsih, Prima Gusti Yanti, SistemInformasi Manajemen Pendidikan, Bumi Aksara, Jakarta, 2008.
LPM UIN SUSKA RIAU, Pedoman Pelaksanaan Kuliah Kerja Nyata (KKN) Pengabdian Kepada Masyarakat Tematik Pemberdayaan Berbasis Masjid, 2012, Pekanbaru: UIN SUSKA Riau, 2012.

Farida Yusuf Tayibnapis, Evaluasi Program dan Instrumen Evaluasi untuk Program Pendidikan dan Penelitian, Jakarta; Rineka Cipta, 2008.

Fitzpatrick Jody, Christie Christina, Melvin M. Mark, Evaluation in Action,Los Angeles: SAGE Publications, 2009.

George F. Madaus and Daniel L. Stufflebeam, Program Evaluation Program Evaluation dalam Evaluation Models Viewpoints on Educational and Human Services Evaluation Second Edition, Boston: Kluwer Academic Publisher, 2006

Hartina tentang Pengaruh Evaluasi Context, Input, Process, Product (CIPP) Sumber Daya Manusia Terhadap Kinerja Dosen Studi Pada Sekolah Tinggi Agama Islam Yayasan Pendidikan Nasional Jeneponto. Tesis Universitas Hasanuddin, 2015

Hikmat, Harry., Strategi Pemberdayaan Masyarakat (Edisi Revisi), Bandung: Humaniora Utama Press, 2004.

Huey-Tsyh Chen, The Roots of TheoryDriven Evaluation, Evaluation Roots (California: Sage Publication Inc), 2004.

Ife, J. Tesoriero, F., Alternatif Pengembangan Masyarakat di Era Globalisasi, Community Development, Cetakan 1. Yogyakarta: Pustaka Pelajar, 2008.

I Gusti Ngurah Putrajaya, Nyoman Dantes, I Made Yudana tentang Studi Evaluatif Berbasis Model Context, Input, Process, Product Terhadap Pelaksanaan Pendidikan Sistem Ganda (PSG) di SMK Negeri 1 Masubud Pada Jurusan Multimedia. (e-Journal Program Pascasarjana Universitas Pendidikan Ganesha Program Studi Pendidikan Dasar, Volume 3 Tahun 2013) 
James C. McDavid, Laura R.L.Hawthorn, Program Evaluation \& Performace Measurement, An Introduction to Practice (London: SAGE Publications), 2006.

Jamasy, O., Keadilan, Pemberdayaan, \& Penanggulangan Kemiskinan. Jakarta Selatan: Blantika, 2004.

Liunir Z, Evaluasi Pelaksanaan Program Pendidikan Keterampilan Kerumah tanggaan Dan Kepariwisataan di Sekolah Menengah Pertama Negeri 3 Lembang, Disertasi Universitas Pendidikan Indonesia, 2006.

Madaus George F, and Kellaghan Thomas, Models, Methaphors, andDefinition in Evaluation, dalam Evaluation Models, New York: Kluwer Academic Publishers,2000.

Martinson Karin and O'Brien Carolyn, Conducting Case Studies, San Francisco: Josey-Bass,2010.

Marvin C. Alkin, Christina A. Christie, An Evaluation Theory Tree, dalam Evaluation Roots (California: Sage Publications, Inc, 2004

McDavid James C., and Hawthorn Laura R.L., Program Evaluation \&PerformaceMeasurement, $\quad A n$ Introduction to Practice, London: SAGEPublications, 2006.

Mukhneri Mukhtar, Manajemen Sistem, Jakarta: BPJM FIP UNJ, 2012.

Muchlis R. Luddin, Ologarki Kebijakan Pendidikan, Jakarta, PT. BinaBangsaNusanta, 2012.

Ngalim Purwanto, Prinsip-prinsip dan Teknik Evaluasi Pengajaran, Jakarta: Rosda, 2009.

Owen John, Program Evaluation, Form and Approach, Australia: Allen \&Unwin, 2006.

Oxford Universiy, Oxford Advanced Leaner's Dictionary of Current English, China: Oxford University Press, 2011.

Peter H. Rossi, My Views of Evaluation and Their Origin, dalam Evaluatioan Roots (California: Sage Publications. Inc), 2004. 